\title{
TEACHING LANGUAGE THROUGH LITERATURE: THE WASTE LAND IN THE ESL CLASSROOM ${ }^{1}$
}

\author{
Pilar Agustín Llach ${ }^{2}$
}

\begin{abstract}
This article intends to show how literature may be used in language classes to develop student's knowledge of English. First, we examine the evolution of literature in the language classroom, then we give account of some reasons that justify its use in language classes, of the role of reading in language development, and of the way poetry is treated in the ESL classroom. The Waste Land is a good work to be used as a tool to develop student's communicative competence in English. The article ends with a didactic proposal for ESL instruction based on the poem.
\end{abstract}

Key words: Literature and language teaching, ESL, The Waste Land, reading.

Resumen: Este artículo pretende demostrar cómo la literatura puede contribuir a desarrollar el conocimiento de los alumnos en la lengua extranjera inglés. Primero examinamos la evolución de la literatura en la clase de lengua y damos cuenta de las razones que justifican su uso, del papel de la lectura en la adquisición de la LE, y del tratamiento de la poesía en clase de LE. The Waste Land es una obra adecuada para ser usada como instrumento para desarrollar la competencia comunicativa del aprendiz en inglés. El artículo termina en una propuesta didáctica para la instrucción del inglés basada en el poema.

Palabras clave: La literatura en la enseñanza, inglés lengua extranjera (LE), The Waste Land, lectura.

\section{INTRODUCTION}

This paper aims to pinpoint the relevant role of literature as a resource for second language teaching. Here the focus will be on the use that language teachers may make of the modernist text The Waste Land in order to help students develop their proficiency in English. Literature supplies many linguistic opportunities to the language learner and allows the teacher to design activities that are "based on material capable of stimulating greater interest and involvement" than many other non-literary, informative texts (Carter and Long 1991: 3). The aim of these activities should be to focus on the form and content of the text at stake, and to provide the stimulus for interaction to take place between the learners among them, and with the teacher (Duff and Maley 1990: 3).

This paper is framed within the communicative approach to language teaching. This implies that the development of communicative competence should be the last aim of any language activity. The relevance of literature in this approach is, on the one hand, that it

Date of reception: March 2007.

Date of acceptance and final version: April 2007.

2 Assistant Lecturer, Departamento de Filologías Modernas, Universidad de la Rioja; $\square$ maria-del-pilar. agustin@unirioja.es. 
transmits messages. It is a way of communication between the author and the reader. On the other hand, literature pays special attention to form, and this helps the learner reflect about language, another principle and goal of the communicative method. It is important that the learners develop their linguistic competence by learning how to express meanings in English, but also that they develop their communicative competence, that will allow them to transmit messages, to use the language to interact, to communicate with other people, which is, in the end, the basic function of language. The use of literature as a teaching tool is legitimated by the facts mentioned above, namely, because it provides with authentic linguistic (also sociolinguistic) and cultural material, and because it motivates the learners to interact.

The literary text chosen belongs to the modernist tradition and has never been used in the literature as a language teaching resource. The poem The Waste Land is very much adequate for teaching due to its high pedagogic potential both as regards its content and its form. The modernist ideas and philosophy underlying the poem result of an extremely high interest for learner, who may very well feel identified with the poet or narrator of the poem.

This paper is divided into three main sections. The first one is theoretical and explains the use that of literature in general, and of poetry in particular, is being made as a resource for second language teaching. The second section deals with the examination of the reasons why the poem by T.S. Eliot The Waste Land is thought to be appropriate for such an approach. The final section is practical and collects a number of suggestions for classroom activities to be carried out with the poem to enhance language learning as well as literary awareness.

\section{LITERATURE IN LANGUAGE TEACHING}

\subsection{Historical evolution}

Literature and language are closely related and this is a fact none can deny. Literature is constituted by language and it represents one of the most recurrent uses of language. Language and linguistic analysis can also be employed to access literature from the learner's point of view. Brumfit and Carter (1986: 1) already emphasized the role of literature as "an ally of language". This technique is by no means novel, since literature has been a widely used teaching tool in different language teaching methods. However, here the perspective changes giving more relevance to the literary text as a work of art. First of all, let us go over the changing role of literature in the tradition of second language teaching to end with an account of its current situation within the communicative approach.

In the grammar translation method, literature was the central component. Literary texts of the target language were read and translated, used as examples of good writing and "illustrations of the grammatical rules" (Duff and Maley 1990: 3). The focus of this teaching method was on form, on learning the rules of grammar and the lexical items as they appeared in the text. There was no literary interest, nor interest on content. After this method fell in disuse, literary texts also went forgotten for teachers of second languages. 
For the structural approaches to language teaching, literature was discredited as a tool, because it represented the old tradition. The functional-notional method ignored literature, because in this method the importance lies on communication and they present authentic language samples. Literature was not considered either to have a communicative function nor to be authentic example of language use.

Nonetheless, in the last decade or so the interest in literature as one of the most valuable language teaching resources available has revived remarkably (Duff and Maley 1990: 3). This is in consonance with the new currents within the communicative approach that see in reading literature the perfect realization of their principles, namely developing communicative competence, that is teaching learners to communicate in the second language and accounting for real, authentic communicative situations (Sanz and Fernández 1997).

Literature reading is, no doubt, a communicative activity and literary texts are, who could nowadays deny such thing, authentic examples of language use. Many authors, among them Brumfit and Carter (1986) and Lazar (1993), reject the idea of the existence of a specific literary language and claim that the language used in literary texts is common language with a high concentration of linguistic features like metaphors, similes, poetic lexis, unusual syntactic patterns, etc. (see Lazar 1993: 7 for a more detailed account of the characteristics of the literary use of language). These are not literature specific since these features also appear in ordinary language use and also in nursery rhymes, proverbs or publicity slogans, just to cite a few examples, however, in literature these show a higher incidence. We talk therefore, of a literary use of language.

\subsection{Examining the reasons for using literature in the language classroom}

We could argue that there are three main criteria that justify the use of literature as a second language teaching tool (Duff and Maley 1990: 6). In the first place, the linguistic criterion defends that literature should be used in language teaching, because it provides the learner with genuine, authentic samples of language, and also with real samples of a wide range of styles, text types and registers. It is extremely important for foreign language learners to be trained in a variety of registers, styles and genres and to be able to discern the function of each of them. These different manifestations of language are not only distinctive linguistically, but also socially, they all have a social communicative function (Sanz and Fernández 1997). This has to do with the notion of adequacy. It refers to the fact that a message needs to be linguistically correct and situationally appropriate, as regards not only its content, but also its form (see Llobera 1995, Sanz and Fernández 1997, Cassany 1999 for a more detailed account on the notion of adequacy and its relationship to communicative competence).

The second criterion is methodological and refers to the fact that a literary text has multiple interpretations, these generate different opinions among the learners and this leads to real, motivated interaction with the text, with the fellow students and with the teacher (Widdowson 1983). Interaction is one of the bases of the communicative approach which defends that it is by interacting, by communicating, that the language is learned (Sanz and Fernández 1997). From the methodological point of view, further aspects that favour the use of literature in the language classroom are the active role of the learner and the literary 
text as the central focus of attention. Learners become active, autonomous, and central to the learning process. One aspect of special importance within the communicative approach, and that is magnificently reflected in the poem at stake, is the idea of literature supplying the learner with cultural information about the country whose language they are learning (Lazar 1993: 16). Poetry is fictional and, therefore, we must be very careful when treating this point in the classroom, for sometimes its relation to the real world is rather lax. Our response to the cultural aspect as reflected in literature should be critical (Lazar 1993: 17).

Finally, the motivational criterion is of great relevance because the literary text shows the real feelings of the writer and this generates a powerful motivation in the learner. With the literary text the student accesses this personal experience, if she is touched by the theme and provoked, she will be able to relate what she is reading to her world, to what she knows and feels. Designing stimulating activities that motivate the learners is the greatest challenge for language teachers, and literature has a strong motivating power due to its calling on to personal experience.

\subsection{Reading as an aid for language development}

Underlying the claim to using literature to develop linguistic and communicative competence is the assumption that reading is one of the best ways of learning a language. Be it consciously or unconsciously, reading helps the second language learner acquire not only more vocabulary and more meanings and uses of the words already known (lexical competence), but it also contributes to develop syntactic knowledge (Brumfit and Carter 1986). Krashen (1989) and Coady (1997) argues that it is through extensive reading, that learners acquire most of their vocabulary, and that instruction plays a rather insignificant role as the number of words learned is concerned. Paribakht and Wesche (1997) are also of the same opinion. For Grabe and Stoller (1997), reading contributes greatly to vocabulary development and also to listening comprehension.

Therefore, reading literature is positive in several ways. It presents with authentic and varied language material, it provides with contextualized communicative situations, real patterns of social interaction, and use of language (Collie and Slater 1987: 2), it highlights the central role of the learner in the learning process and stirs up interaction in the classroom, it motivates learners by allowing them to relate what is being read to their own experience since it calls on emotional responses (Collie and Slater 1987: 2), and it contributes largely to develop further reading skills like "deducing the meaning and use of unfamiliar lexical items", "understanding the communicative value (function) of sentences and utterances", "recognizing the script of a language", etc. (Grellet 1981: 4-5). Using literature to teach language not only contributes to a better linguistic understanding, a development of creative skills, and a higher language proficiency, it also makes an important contribution to literary appreciation (Ramsaran 1983: 42).

\subsection{Poetry in second language teaching}

Among the literary genres used in language teaching, poetry is one of frequent appearance. Due to their short length, perfectly suitable for a single classroom lesson, their peculiar 
structure, their characteristic linguistic features (unusual syntactic patterns, polysemy of words, alliteration, etc.) poems become favourite tools for language teachers. The evocative character of poetry, its imagery, its appeal to feelings and personal experience make it very interesting and enjoyable for the second language learner. Especially, poetry can lead to a desirable creative expression in the foreign language and they usually provoke a strong response from the reader which will motivate further reading (Collie and Slater 1987: 226).

The importance of poetry and its usefulness in language classroom lies in the fact that poetry deviates from normal language in that it has some unusual ways of ordering words, or it attributes particular, imaginative meanings to words or combines sounds in a musical, non ordinary way (phonological, lexical, syntactic, semantic, graphological, and style deviation (Ramsaran 1983: 36). The language teacher should exploit the deviancies of the poetic language in order to arise the language awareness of the learners towards the way in which language can be adapted or changed to fulfill different communicative purposes.

\section{WHY THE WASTE LAND?}

"The key to success in using literature in ESL class seems to me to rest in the literary works that are selected" (McKay 1986: 193). The Waste Land offers great pedagogical opportunities for its magnificent language and language use, and its controversial underlying philosophy.

\subsection{Content}

From the point of view of a content analysis, the poem displays a series of features that make it very interesting for the language classroom. First of all, the poem is one of the most relevant literary works of the last century. Both literary and culturally it marked a turning point. It challenged the established standards and brought about a new current: modernism, that invaded all fields of cultural manifestations, not only in literature, but also in architecture or painting. This poem changed "the face of the twentieth century culture" (Selby 1999: 7). After the Great War, Europe, its fields and its people were left exhausted. The horrors of the war, the physical, emotional, political and cultural devastation and chaos that it left behind inspire The Waste Land. T.S. Eliot, the author, like many of his contemporaries, was convinced that the old cultural and social values, norms and beliefs had been blown apart by the war and the new experiences (Selby 1999: 7). They were no longer valid and a feeling of loss and of abandonment replaced them instead. Modernism can be compared to youth, because in this time of life there are many new experiences going on. Learners may feel the poem is telling in some way their life, the way they feel, their thoughts and feelings. They may identify with the poet and feel he is somehow telling their story of uneasiness in some moment of their lives; "it is important to select themes with which the students can identify" (McKay 1986: 194). Here rests the relevance and interest of The Waste Land. Its reading both creates and demands a high degree of personal involvement from the learner. The poem allows for many interpretations, since it displays a series of mythical and symbolic parts which are for the reader to interpret basing on his 
own experience, on his "mental and emotional structures" (Traversi 1976: 14), here we have the learners involved to their utmost in the poem.

Despite its fictional character, The Waste Land is a good way to increase the cultural enrichment of the learners by providing them with an insight into the past (tradition) and modern culture of "the country whose language is being learnt" (Collie and Slater 1987: 4). One of the most recurrent and relevant allusions of the poem is tradition, therefore, culture and past times play an important role in The Waste Land.

The poem The Waste Land is, therefore, culturally and literary relevant, in consonance with the learner's cultural background. It is motivating, it allows for personal involvement and cultural enrichment. Learners can draw from the poem and relate it to their personal experience. They create their own poem as they interact with it, and this interaction implies involvement in the reading of the poem.

\subsection{Form}

It is a long poem, whose organization is rather fragmentary. This allows the teacher to design activities and organize term classes at two levels. On the one hand, the individual fragments of the poem can be used for each single lesson, for example as divided by Eliot, or he may find an alternative fragmentation; on the other hand, the poem may be used for several sessions over one or two weeks. It has the advantage that it tells many different stories within the frame of a longer story, a kind of "superstory", and this can be exploited by developing multiple exercises that deal with each sub-theme and with the general theme. As Eliot acknowledges himself in the poem, it is "a heap of broken images", where voices and characters succeed one another and superpose. This novel organization and representation of experience is very motivating and will engage learners in genuine decoding of communicative meaning.

Its unusual associations of words (collocations) or the peculiar meanings attributed to some words or expressions: "April is the cruelest month", "stirring dull roots with spring rain", "winter kept us warm" etc. can be used by the teacher to have the learner reflect on the nature of the foreign language and on the different purposes that can be achieved by modifying the regular word order, altering the expected meaning of a word or inventing new combinations of two lexical items (see Reeves 1994 for more examples and a further explanation of "linguistic alienation" and "linguistic attraction").

Another reason why we chose to work with The Waste Land is that it is a contemporary work and therefore, its language is modern and understandable. The combination of different languages (Latin, Italian, German, etc.) that appear in the poem is also very interesting and appealing for the learners. The teacher can make them reflect about the purpose of using those different languages and the effect achieved by this, helping them, thus, to develop their knowledge of the rules of social use, together with the rules of grammar.

We are aware of the linguistic and conceptual difficulty of the poem. The fact that there are difficult areas, that the learners can overcome, is challenging and motivating and it is a further incentive to read and work on the poem. It is essential to make clear that experts show preference for authentic, non-simplified texts, since they are much more valuable from the linguistic point of view, because they provide real language in context and natural 
stimuli, by the exploration and discussion of content, that lead to examination of language (Brumfit and Carter 1986: 15). Grellet (1981: 7) claims that the difficulty is not on the text itself but on the exercises that are required of the students.

Literature can improve reading comprehension to a great extent, because reading proficiency rests on the interaction between reader and writer, interaction mediated by the text (McKay 1986: 192). The more motivating and enjoyable the text, the more intense, real and powerful the interaction will be (Brumfit and Carter 1986: 15). When reading The Waste Land, learners are communicating, deciphering meanings and reflecting on language and communication strategies in the foreign language, this a "crucial factor in the development of language learning abilities" (Brumfit and Carter 1986: 14). Cassany (1999) goes a bit further and claims that reading aids develop writing abilities by spurring their own imaginative writing and by providing them with examples of language use.

\section{PROPOSAL OF ACTIVITIES TO IMPLEMENT WITH THE WASTE LAND}

These activities are thought to be some guiding outline to the work with The Waste Land as a language teaching resource. They are addressed to intermediate-advanced learners of English at University level. Following Maley (1996) we will divide our exercises into four main sections: responding, analysing, writing, and experiment further.

Responding: these are what traditionally has been called pre-reading activities:

1. Think with a partner of a situation where you felt sad, or even desolated. This may give rise to a myriad of responses, for example when left by the beloved person, when someone in the family died, or when failing in an exam.

2. Deducing from the title. What do you think the poem is about? Work in pairs. Here we may expect answers such as: a war, an epidemic that killed many in a small region, destruction of fields or crops by the enemy, abandonment of the family, poverty due to lack of rain and dried crop.

3. Think of things that may "waste" a land, or a person. Brainstorming with the whole class, the teacher writes down on the blackboard. Students may come up with words such as abuse, floods, draught, hard work, stress, tension, and so on.

4. With your partner, think of a general context out of which such a poem could have come to be: country, epoch, personal situation of the poet, economic and political happenings, etc. For example, learners may think of a family in the Middle Ages, whose fields have been devastated by a flood and who are starving. The whole county and country, for example England, is suffering from an epidemic due to the floods, and the poet, the son of the poor family decides to write his story.

With these initiating activities, the teacher smoothes the path of the reading exercise and guides the learners to what they will be dealing with the next days. It is important the learners predict what will come and that they have some previous idea of what they are going to read. This is a very important strategy not only in language learning, but also in communication (Maingay 1983). 
5. Read the poem at home.

Analysing: the activities in this section lead to a deeper analysis of the poem both as content and form are concerned: local and global vision.

General Comprehension Questions (global approach).

6. What is the poem about? Where is it set? What is the central theme of each of the five parts of the poem? Here the teacher should provide the learners with some kind of background information about the general epoch of the poem and the events that were taking place in Europe at that time. Providing background information to the learners is a very good help to improve their understanding of the text, and thus, enhance the pedagogical effect of the activities carried out (Lazar 1993: 38). There exist several ways of presenting this information, as a minilecture, as a reading or listening comprehension or as a research project for students to implement (Lazar 1993: 38).

Local analysis

7. The poem The Waste Land has the peculiarity, as you have observed, of being "split up" into many different thematical and structural fragments. With a partner identify those different fragments and think of an adjective or expression that best defines that particular fragment. The fragments they may identify can be: The burial of the death, the maimed Fisher King, the slow, sad passing of the seasons and the coming of the cold winter, etc. The words or expressions used to describe these fragments can be death, desolation, sadness, loneliness, coldness.

8. a) All the class, think of some expressions or adjectives that define the feelings that the poem provokes in you.

b) War, fragmentation, death, desolation, sadness, destruction, loneliness are some of the feelings the poem attempts to arise in the reader. Find with your partner the passages, metaphors or allusions in the poem that mostly provoke those feelings in you and the ones you commented on before in $8 \mathrm{a}$ ), or the passages the poet intended to provoke you those mentioned feelings.

c) Try to find, with the use of a dictionary, the opposites of the words you used to define the feelings you got when reading The Waste Land.

With these exercises, we use the recurrent fragmentation of the poem and the repeated allusions to death and desolation to develop the lexical competence of our students. Vocabulary exercises base here on feelings of sadness and loneliness which will, no doubt, make the learner interact in the classroom and in the group.

9. a) Look carefully at the first part of The Waste Land, "The burial of the death" and try to delimit the main themes. Clue: think of the recurrent idea of death and destruction and consider the verse: "mixing memory and desire" (line 2-3). Work in pairs. They may pinpoint as recurrent themes of the first part the following: fear of death, but recognition of its presence in modern life, life under the earth, hope for the future, tradition, spiritual desolation, love. 
b) Find the themes you have just talked about in the remaining sections of the poem and try to see where they find their unity. Learners may find Tiresias as the one who unites the poem, every theme boils down to this mythological character.

This exercise is aimed to direct students towards a further understanding of the poem.

10. Round all regular verbs that you find and underline irregular ones. Establish the tense they are in (simple past, present perfect, conditional, etc.) and try to determine their function. Do the same with the modal verbs you encounter in your reading.

This is grammar practice.

11. We have already talked about the fragmentary structure of the poem, there we can see different forms of telling a story: description, narration, dialogue; try to identify them in The Waste Land. Can you also think of a communicative purpose for the use of each of them in the concrete situation?

12. As you have observed, in the poem there are several dialogues. With a partner work to transform these into "habitual", colloquial, today English.

13. Practice reading aloud some stanzas of the poem in small groups. What do you notice about the rhythm, speed, intonation?

14. Think with a partner of things that make you feel sad and that make you frightened. Write them down in a list and write simple sentences with those words or expressions. Learners may write down things such as war, poverty, violence, abuse, or loneliness.

Writing. This section bases on the idea that through reading writing abilities can also improve. It is important that we help our students to develop their writing skills in the foreign language.

15. Write a short poem, only 10 lines, where you express you fears and sadness. Use the sentences and the words listed with your partner. Work alone.

16. Choose ten words from the poem that have to do with hope for the future and use them to write a short text with them with the title Hope for the future.

17. a) What do you think the author looked like? With a partner list a series of characteristics you think he may have had, both physically, you may even draw him, and mentally. Think of where he may have been born, what his occupation might have been, apart from writing poetry, or whether he had a family.

b) Then, invent and write a biography for the author.

The list of activities that could be included in this section is immense. We can think of selecting a word form the poem, elaborate a semantic family and create a poem out of them, completing parts of the poem, reshaping the poem, write a critic of the poem, and so on (see Maley and Duff 1990, Carter and Long 1991, Collie and Slater 1994, Maley 1996 for further ideas of activities). 
The experimenting further section, can be carried out by implementing a comparison of the poem of T.S. Eliot, with some previous and some posterior poems to see the differences at the thematical (symbols, conventions, topics) and structural levels.

The implementation of these activities can extend over one class period, but as we have already said above, this intends to be an outline of suggestions to use the poem The Waste Land as a resource for the teaching of English within the principles of the communicative approach. These lay importance on the development of social competence, of showing our students how to communicate in real life situations in the foreign culture and in the foreign language. The teacher has the responsibility of guiding her students to "learn to learn". This refers to the capacity of students to develop their own learning, their autonomy as language learners, and also why not, help them to discern by their own on the literary quality of a work.

\section{CONCLUSION}

This paper has examined a possible application of the poem by T.S. Eliot The Waste Land to the English second language classroom. After having stated the increasingly popular use of literature in the foreign language classroom, a justification of the selection of the poem The Waste Land has followed. Both formally and thematically it is an interesting poem, its strong motivational power cannot be denied, the poem also displays real, current language, which is, from the point of view of the methodological approach (communicative approach) extremely important. The Waste Land is culturally, historically and literary relevant, for which its use and study called on. Furthermore, the poem is an enjoyable piece of literature, which learners will be pleased to read.

With the proposal of activities, it has been seen that working on such a poem, not only literary competence can be developed, but also lexical, morfosyntactic and social- communicative competence. If the activities and their implementation are appropriate The Waste Land can be a useful tool in ESL classrooms.

\section{REFERENCES}

BRumFit, C.J. and A. C. RonALD, eds. 1986. Literature and Language Teaching. Oxford: Oxford University Press.

CARter, R. and M. Long, eds. 1991. Teaching Literature. London: Longman.

Cassany, D. 1999. Construir la escritura. Barcelona: Paidós Comunicación.

CoAdy, J. 1997. "L2 vocabulary acquisition through extensive reading”. Second Language Vocabulary Acquisition. Ed. J. COADY and T. Huckin. Cambridge: Cambridge University Press. 225- 237.

Collie, J. and S. Slater, eds. 1987. Literature in the Language Classroom. Cambridge: Cambridge University Press.

Duff, A. and A. Maley. 1990. Literature. Oxford: Oxford University Press. 
Grabe, W. and F. Stoller. 1997. "Reading and Vocabulary Development in a Second Language: A Case Study". Second Language Vocabulary Acquisition. Ed. J. COADY and T. Huckin. Cambridge: Cambridge University Press. 98-122.

Grellet, F. 1981. Developing Reading Skills. Cambridge: Cambridge University Press.

Krashen, S. 1989. "We Acquire Vocabulary and Spelling by Reading: Additional Evidence for the Input Hypothesis". The Modern Language Journal 73, 4: 440-464.

LAZAR, G. 1993. Literature and Language Teaching. Cambridge: Cambridge University Press.

Llobera, M., ed. 1995. Competencia comunicativa. Madrid: Edelsa.

Maingay, S. 1983. Making Sense of Reading. Hong Kong: Nelson Harrap.

McKay, S. 1986. "Literature in the ESL Classroom." Literature and Language Teaching. Ed. C.J. Brumfit and R.A. Carter. Oxford: Oxford University Press. 191-198.

MALEY, A. 1996. “That's for your poetry book!". Language, Literature and the Learner. Ed. R. CARTer, and J. McRae. London: Longman. 100-114.

PARIBAKHT, T.S. and M. Wesche. 1997. "Vocabulary enhancement activities and reading for meaning in second language vocabulary acquisition". Second Language Vocabulary Acquisition. Ed. J. CoAdY and T. Huckin. Cambridge: Cambridge University Press. 174-200.

Ramsaran, S. 1983. "Poetry in the language classroom". ELT Journal 37, 1: 36-43.

ReEves, G. 1994. T.S. Eliot's The Waste Land. Hemel Hempstead: Harvester Wheatsheaf.

Sanz, M., and C. Fernández. 1997. Principios Metodológicos de los Enfoques Comunicativos. Madrid: Fundación Antonio Nebrija.

Selby, N., ed. 1999. T.S. Eliot The Waste Land. A Reader's Guide to Essential Criticism. New York: Palgrave Macmillan.

Traversi, D. 1976. T.S. Eliot: The longer Poems: The Waste Land, Ash Wednesday, Four Quarters. London: Harcourt Trade Publisher.

WidDowson, H.G. 1983. "H.G. Widdowson on literature and ELT”. Talking Shop, ELT Journal 37, 1: 30-35. 